\title{
Mesodinium rubrum: the phytoplankter that wasn't
}

\author{
David W. Crawford \\ Department of Oceanography, The University, Southampton SO9 5NH, United Kingdom
}

\begin{abstract}
Recent reports suggest that the potential phototrophic role of plastidic ciliates in marine ecosystems may be considerable. A critical review of the literature demonstrates some confusion surrounding acceptance of the trophic position of even a well-established example of a photosynthetic ciliate, Mesodinium rubrum. Despite good evidence of obligate phototrophy from bloom studies, this species has, until recently, been omitted from the majority of routine phytoplankton counts, and has either been assigned to the microzooplankton or completely overlooked. Moreover, problems involved with sampling, enumeration and estimates of productivity for $M$. rubrum are also highlighted from the literature. These principally result from extremes of fragility, motility and vertical aggregation, which are commonly noted for this ciliate. Several recent studies, which have minimized some of these sampling problems and grouped the microplankton into more meaningful ecological categories, suggest that $M$. rubrum has an extremely widespread distribution and can be a very significant member of the phytoplankton. The combination of trophic and methodological difficulties appear to have compounded a serious underestimation of the contribution of $M$. rubrum to the primary productivity of coastal, estuarine and upwelling ecosystems, during both bloom, and perhaps more significantly, non-bloom conditions.
\end{abstract}

\section{INTRODUCTION}

Despite prolonged awareness of the presence of pigmented bodies in pelagic marine ciliates (e.g. Lohmann 1908, Leegard 1920, Kahl 1930-1935), it was not until the late 1960 's that a potentially autotrophic role for chloroplast-bearing ciliates was first convincingly demonstrated through studies on blooms of Mesodinium rubrum Lohmann (Bakker 1967a, Ryther 1967, Barber et al. 1969), an unidentified oligotrich (Burkholder et al. 1967), and a Prorodon-like species (Holm-Hansen et al. 1970).

\footnotetext{
- The name Mesodinium rubrum Lohmann is retained here rather than the more recently proposed Myrionecta rubra Jankowski (see Small \& Lynn 1985), as many populations exhibit the bifurcate 'oral tentacles which that description presumes to be lacking (Lindholm et al. 1988). The unique 14 microtubule structure of these oral tentacles has recently been described by Lindholm et al. (1988). Cylotrichium meunieri Powers is considered conspecific with $M$. rubrum (Fenchel 1968, Taylor et al. 1971), and photosynthetic forms of Mesodinium pulex Claparède et Lachmann are assumed to represent $M$. rubrum. Taxonomic difficulties have been ignored for the purpose of this contribution. However, it is accepted that $M$. rubrum may eventually be shown to represent a species complex, rather than a single species (Lindholm 1985).
}

Even though the photosynthetic capabilities of these forms, particularly Mesodinium rubrum, are now beyond doubt, most research has been carried out during blooms and surprisingly little is understood of their contribution as primary producers to the planktonic community under non-bloom conditions. However, several recent studies have demonstrated $M$. rubrum to be a significant, often dominant phototrophic member of the marine microplankton during certain periods of the year (e.g. Revelante \& Gilmartin 1983, 1987, Leppänen \& Bruun 1986, Stoecker et al. 1989).

An important ecological role has also been suspected for other chloroplast-bearing ciliates since the studies of Blackbourn et al. (1973) and later Mamaeva (1985). Laval-Peuto et al. (1986), Montagnes et al. (1988b), and Lindholm \& Mörk (1989) have shown chloroplast retention in a number of ciliates at the morphological and ultrastructural levels, and, with a more physiological approach, Stoecker et al. (1988) demonstrated obligate mixotrophy in the ciliate Laboea strobila Lohmann. The ecological role of plastidic ciliates has been fully emphasized in recent studies by Jonsson (1987), Stoecker et al. (1987, 1989) and Laval-Peuto \& Rassoulzadegan (1988).

Taylor et al. (1971) and Lindholm (1985) have 
reviewed the information relating to bloom occurrence, taxonomic problems and ultrastructure of Mesodinium rubrum, but did not consider in detail the relative importance of this species as a primary producer under normal' conditions. The present paper reviews literature concerning acceptance of the trophic position of M. rubrum under such conditions, with a view to stimulating examination of the role of phototrophic and mixotrophic ciliates generally, for which little ecological information is available.

In addition to these trophic considerations, a number of important methodological difficulties concerning Mesodinium rubrum are also addressed and reviewed, particularly those relating to behavioural, structural, and physiological peculiarities of this curious ciliate.

\section{TROPHIC CONFUSION}

Without its capacity to form red-water, Mesodinium rubrum could well have long remained unknown as a primary producer (Lindholm 1985).

The pigmented bodies noted by earlier authors (e.g. Lohmann 1908, Leegard 1920) were later identified as chromatophores with associated pyrenoid bodies (Powers 1932, Bary \& Stuckey 1950). More recent studies also examined mass occurrences of Mesodinum rubrum (Bakker 1966, 1967a, Fonds \& Eisma 1967, Ryther 1967. Fenchel 1968, McAlice 1968, Parsons \& Blackbourn 1968, Barber et al. 1969, Taylor et al. 1969, 1971), all of which either suspected or verified its photosynthetic ability. Packard et al. (1978), Smith \& Barber (1979), and Cabecadas et al. (1983) demonstrated it to be an exceptionally productive phototroph. During a dense oceanic bloom in the upwelling area off the coast of Peru, Smith \& Barber (1979) measured values for chlorophyll a as high as $1000 \mathrm{\mu g}^{-1}$, an assimilation number of $16.8 \mathrm{mg} \mathrm{C}$ $(\mathrm{mg} \mathrm{Chl} \mathrm{a})^{-1} \mathrm{~h}^{-1}$ and productivity of over $2000 \mathrm{mg} \mathrm{C} \mathrm{m}^{-3}$ $\mathrm{h}^{-1}$. Taylor (1982) considered this productivity rate to be the highest aquatic micro-organismal primary productivity on record. He also suggested the association between $M$. rubrum and its cryptomonad symbiont to be the most strongly integrated known, between host and photosynthetic cytobiont.

Despite this remarkable photosynthetic capacity, it is ironic that confusion has surrounded the phototrophic role of this ciliate under non-bloom conditions. The reasons for this are not clear, since no convincing evidence of heterotrophic feeding has been presented and intact chloroplasts appear to be present throughout the year (Taylor et al. 1971, Lindholm 1985, Crawford pers. obs. Southampton Water). It is possible that the highly variable size distribution (see Leegard 1920, Michanek 1965, Taylor et al. 1971, Lindholm 1985, Montagnes \& Lynn 1989, Crawford pers obs. Southamp- ton Water) may, in part, have generated taxonomic and thus trophic uncertainty (e.g. see Revelante \& Gilmartin 1987). Sorokin $(1979,1981)$ and Tumantseva (1985) suggested that Mesodinium rubrum combines phototrophy with phagotrophy upon bacterioplankton, but provide little clear supporting evidence. This view is not supported by observations that $M$. rubrum lacks a true cytostome (Bary \& Stuckey 1950, Taylor et al. 1971, Hibberd 1977, Grain et al. 1982, Lindholm et al. 1988). Bakker $(1966,1967 \mathrm{a}, \mathrm{b})$ favoured the idea that $M$. rubrum is a temporary photosynthetic modification of the colourless Mesodinium pulex Claparède et Lachmann, with an accompanying degeneration of the cytostome. Tamar (1971) described such a dimorphism in the oral cone of a related species, Mesodinium fimbriatum Stokes, however, Taylor et al. (1971) have pointed out that the exceptional thinness of the pellicle of $M$. rubrum, with reduced alveoli, is a major modification unlikely to be accomplished on a short term basis. $M$. rubrum has only been shown to behave heterotrophically in the sense of active amino acid uptake (Smith \& Barber 1979), a capability shared by a number of autotrophic forms (e.g. Hellebust 1970). However, it cannot survive in darkness in the laboratory for more than a few days (Taylor et al. 1969, 1971, Lindholm 1985).

Although earlier descriptive microplankton studies (e.g. Leegard 1920) did not specify the trophic mode of Mesodinium rubrum at non-bloom densities, some later ones (e.g. Michanek 1965) placed the ciliate within the microzooplankton category. However, despite the developing interest in the photosynthetic ability of $M$. rubrum in the late 1960 's, many later studies continued to classify it as a microzooplankter (e.g. Takahashi et al. 1975, Beers et al. 1977a,b, Eriksson et al. 1977 , Takahashi \& Hoskins 1978). In some instances, this was due to cautious identification to genus level (e.g. Beers \& Stewart 1971, Dale \& Burkill 1982j. Other studies, briefly noting the occurrence of $M$. rubrum, have not specified its trophic position (Parsons et al. 1977, Burkill 1982, Stoecker et al. 1984). The confusion can be emphasised by contrasting the study of Beers et al. (1971), which assigned relatively low numbers of $M$. rubrum to the phytoplankton, with later works by the same author (Beers et al. $1977 \mathrm{a}$, b) placing it within the microzooplankton. A more recent study by Beers et al. (1980) correctly placed $M$. rubrum back with the phytoplankton.

Microzooplankton and more general microplankton studies from the late 1970 's onwards have gradually acknowledged the autotrophic status of Mesodinium rubrum (e.g. Chester 1978, Lindholm 1981. Smetacek 1981, Revelante \& Gilmartin 1983, 1987, Andersen \& Sørensen 1986, Kivi 1986, Leppänen \& Bruun 1986, McManus \& Fuhrmann 1986, Sherr et al. 1986, Sanders 1987, Laval-Peuto \& Rassoulzadegan 1988, Montagnes 
\& Lynn 1989, Stoecker et al. 1989). This may have partly resulted from a strong recommendation by Sieburth et al. (1978) that $M$. rubrum, being a functional phototroph, should be classified accordingly.

If the microzooplanktologists have appeared rather slow in releasing Mesodinium rubrum from their trophic grouping, then the phytoplanktologists have shown an even greater reluctance in its acceptance. Even now $M$. rubrum is often conspicuously absent from species lists of 'phytoplankton' surveys, even in areas where more specific studies have shown it to be relatively abundant throughout the year. This may in some instances have left $M$. rubrum in an ecological 'vacuum', acknowledged as phototrophic and thus ignored from some heterotrophic ciliate counts (e.g. Smetacek 1981, Kivi 1986), but then perhaps not recognised in corresponding phytoplankton surveys of the same area.

A good example of the complete omission of Mesodinium rubrum from routine counts is given by Gieskes \& Kraay (1983), in a phytoplankton study of the central North Sea. This study demonstrated an absence of cryptophycean flagellates in cell counts, yet using HPLC pigment 'fingerprinting' they detected relatively high levels of alloxanthin, a pigment diagnostic of that algal class. Extremely low phytoplankton carbon: chlorophyll a ratios were also noted, suggesting possible omission of part of the phytoplankton community. Subsequent re-examination by the authors of the Lugol's iodine preserved samples revealed $M$. rubrum in relative abundance ( 25 to 50 cells $\mathrm{ml}^{-1}$ ) and in sufficient numbers for its cryptomonad endosymbiont (Parsons \& Blackbourn 1968, Barber et al. 1969) to contribute to much of the phytoplankton chlorophyll $a$ and alloxanthin. The vast majority of phytoplankton studies do not have the benefit of HPLC as a chemotaxonomic tool. Consequently, significant numbers of $M$. rubrum may well have been ignored on many occasions.

In Southampton Water, UK, Mesodinium rubrum has apparently even been missed as the cause of annual

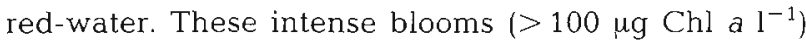
have been known since the turn of the century (Royal Commission 1911), and were then assumed to be caused by a peridinean dinoflagellate, although $M$. rubrum was probably to blame (Williams 1980). $M$. rubrum was first noted as the causative species by Williams (1980) and Soulsby et al. (1984), but received no mention in earlier publications on phytoplankton (Savage 1965, 1967), zooplankton (Raymont \& Carrie 1964, Barlow \& Monteiro 1979), or planktonic oxygen consumption (De Sousa Lima \& Williams 1978). This probably resulted both from confusion in its trophic position and inadequate sampling methods, but again emphasizes the potential underestimation of this species.
There are obviously a number of recent exceptions to the failure to include Mesodinium rubrum in phytoplankton species lists, for example, Reid et al. (1978) and Cullen et al. (1982) in the southern Californian bight, Blasco et al. $(1980,1981)$ in the North-West African upwelling, Holligan et al. (1984) in the Gulf of Maine, Cloern et al. (1985) in San Fransisco Bay, Mackenzie \& Gillespie (1986) and Mackenzie et al. (1986) in New Zealand coastal waters.

Though acceptance of the autotrophic role of Mesodinium rubrum has improved considerably, problems persist with respect to the use of data from previous studies. In view of the relatively recent interest in ciliate trophic dynamics, considerable use can be made of sparse data, which may have been collected before the trophic modes of individual species were known in detail. For example, in a review of trophic dynamics in the Baltic Sea, Elmgren (1984) suggested that the role of ciliates as grazers of phytoplankton, described by Eriksson et al. (1977), was excessive since $M$. rubrum accounted for one third of the ciliate volume estimated in that study.

Failure to recognise the contribution of phototrophic and mixotrophic forms may also make re-analysis of data from previous studies problematical. Data from the earlier studies of Beers \& Stewart (1969a, 1970, 1971 ) in the waters off southern California and in the eastern tropical Pacific has often been quoted in recent comparisons of heterotrophic ciliate abundances, despite the authors concession of the possibility of other modes of nutrition occurring in some species. In southern Californian coastal waters in March 1976, Reid et al. (1978) found Mesodinium rubrum to be an abundant phytoplankton species in the region generally, and the second most important species after Exuviella sp. (= Prorocentrum) with respect to the chlorophyll maximum. Cullen et al. (1982) also found M. rubrum to be abundant in this area in August 1978. However, Goodman et al. (1984) did not mention $M$. rubrum in this region during a study sampling at weekly intervals throughout the spring and summer. Closer examination reveals that this latter statistical study was actually based on a data set collected in 1967 by J. D. H. Strickland's Food Chain Research Group (Eppley et al. 1970, Reid et al. 1970). Although many other factors could be invoked, it would appear unlikely that $M$. rubrum was recorded in routine phytoplankton counts at that time. It is interesting to note that the corresponding microzooplankton contribution (Beers \& Stewart 1970 ) to this study made no particular mention of $M$. rubrum either, though in retrospect the sampling methods (see subsequent sections) may not have been adequate for this species. Other reports do confirm the common occurrence of $M$. rubrum in this region (Lackey \& Glendinning 1963, 1965, Lackey 1967, Beers et 
al. 1980). Future microplankton studies should adopt more ecologically appropriate categories, as recommended some time ago by Sieburth et al. (1978) and emphasised more recently by Sieburth \& Estep (1985).

\section{FIELD SAMPLING LIMITATIONS}

\section{Nets}

The use of nets is not generally considered to be acceptable for the quantitative study of either phytoplankton (Tangen 1978) or microzooplankton (Beers 1978b). Ciliates are particularly susceptible (e.g. Margalef 1967, Beers \& Stewart 1970), due either to physical damage or to cells passing through the mesh. Smetacek (1981) clearly demonstrated the detrimental effect of using nets, upon numerical estimates of non-loricate ciliates in the Kiel Bight. However, nets have been used extensively in semi-quantitative phytoplankton studies (Tangen 1978). The largest cells of Mesodinium rubrum occur during blooms and overlap the net phytoplankton size category. This species has been noted by Lindholm (1985) to disintegrate totally in nets and as a consequence net sampling may have led to some erroneous reports of red-tide causal species (Lindholm 1985). The smaller cells of $M$. rubrum, usually encountered outside of bloom conditions, would either pass right through or disintegrate in even the finest nets used. The use of nets cannot therefore be considered acceptable even for semi-quantitative phytoplankton study, in view of the potential role of $M$. rubrum and possibly other ciliates as primary producers.

\section{Pumps}

Pump sampling is frequently employed as a means of investigating microplankton distributions. Samples for phytoplankton abundance, in particular, are often taken from the pump outflow for continuously monitored chemical and biological parameters. Beers (1978a) has given a detailed review of the use of pumps for sampling the phytoplankton.

Beers et al. (1967) described a pumping/ concentrating system based on a submersible centrifugal pump. for the quantitative sampling and concentration of microzooplankton and phytoplankton. This has been used in several subsequent studies (e.g. Beers \& Stewart 1967, 1969a, b, 1970,1971) which have contributed significantly to much of the current thinking on the role of ciliates in marine ecosystems. The use of these systems is defended by Beers et al. (1967) and Beers (1978a), who suggest that damage can be reduced to negligible proportions. However, Beers et al. (1967) did note significant damage to the more fragile forms such as the the dinoflagellate Noctiluca sp., while Beers et al. (1971) noted damage to aloricate ciliates in unconcentrated samples taken from a pump fitted to the ships hull. Sorokin (1981) has criticized the use of pumps generally, with even the most gentle concentrating procedures, for sampling ciliates, and further suggests that more than $95 \%$ of both naked and loricate forms may be lost by such methods. In view of these criticisms, it appears unlikely that such a delicate species as Mesodinium rubrum (Lindholm 1985) could survive these sampling methods without a noticeable effect on cell numbers. Burkill (1982) did observe a significant reduction in the numbers of $M$. rubrum cells using a submersible centrifugal pumping system, whilst numbers of other microplankton species appeared unaffected. However, the centrifugal type pump is considered by Beers (1978a) to be potentially more damaging to plankters, because of the manner in which water is propelled.

Gentle pumping systems may be more promising, though quantitative information is lacking. For in stance, Grice et al. (1980) noted a significant population of Mesodinium rubrum in a Controlled Ecosystem Pollution Experiment (CEPEX) enclosure in Saanich Inlet, British Columbia, Canada, when sampling with a peristaltic pump. However, such slower intake pumps are more susceptible to the problem of avoidance of the pump intake by the more motile forms (Beers 1978a). Though this problem is usually confined to the larger zooplankton, the well documented swimming capabilities and rheotactic behaviour of $M$. rubrum (Taylor et al. 1971, Lindholm 1985) render it a strong candidate for potential avoidance. Representative sampling of $M$ rubrum using any form of pump system must be considered questionable, at least until adequate quantitative comparisons have been undertaken between different methods. Furthermore, populations of $M$ rubrum enumerated from pumped samples should be considered minimal estimates.

\section{Water bottles}

Water bottles are the most widely adopted device for quantitatively investigating the distribution of phytoplankton and probably represent the most effective means of accurately sampling fragile species. A review of the use of water bottles in phytoplankton sampling is given by Venrick (1978).

Although water bottles may be considered potentially to have the least damaging effect on Mesodinium rubrum, these devices are not without drawbacks and care must be exercised during sampling. In water samplers such as the 'Van-Dorn', which may incorporate 
small 'windows' for the indication of water level, $M$. rubrum could quickly concentrate close to the light source and consequently be undersampled. Although this effect has not been described in a sampling study to date, phototaxis and motility are well documented (Lindholm 1985). This response to light has been effectively utilized by Lindholm (1981) to concentrate $M$. rubrum sampled in low numbers. Similarly, $M$. rubrum has been noted by Cabecadas et al. (1983) to accumulate at the top of a 'Van-Dorn' bottle whilst samples were drawn from the bottom, an effect considered by Lindholm (1985) to result from positive rheotaxis and high swimming speed. Thus, it is recommended that samplers be gently mixed if at all possible, immediately prior to subsampling, which should be done as soon as possible after sample collection.

\section{Vertical distribution and migration}

Though the sampling problems described are not insurmountable, and may be minimized, ignorance of the vertical distribution and migration of Mesodinium rubrum can lead to gross underestimates of its population density. Whilst this is a general caution for much of the motile plankton, M. rubrum is particularly susceptible as a result of its exceptionally high swimming speed (see Lindholm 1985). When hydrodynamical conditions permit, $M$. rubrum forms marked sub-surface and occasionally surface accumulations over extremely restricted depth intervals, both during blooms (Lindholm 1978, Packard et al. 1978, Smith \& Barber 1979, Sorokin \& Kogelschatz 1979, Cabecadas et al. 1983) and under normal conditions (Takahashi \& Hoskins 1978, Lindholm 1981, McManus \& Fuhrmann 1986, Dale 1987a). These characteristic vertical distributions have been shown to result from diurnal vertical migration apparently in response to light. It has been known for some time that $M$. rubrum exhibits a strong phototactic response (Bary \& Stuckey, 1950). Smith \& Barber (1979) further suggested that the diurnal migration resulted from positive phototaxis in increasing light, and negative phototaxis in decreasing light. In the Southampton Water estuary, Soulsby et al. (1984) have also shown an apparently phototactic diurnal migration of $M$. rubrum, while Crawford \& Purdie (unpubl.) have evidence of vertical movements of the population in response to tidal motions, superimposed upon this diurnal pattern.

These migrations can lead to a vertical distribution in which the vast majority of the daytime population may be concentrated close to the surface. Although more pronounced during blooms, sub-surface maxima are a regular feature of the population in Southampton Water, except during strong winds (Crawford pers.
obs.J. Takahashi \& Hoskins (1978) found an average of $>65 \%$ (mostly $>90 \%$ ) of the Mesodinium rubrum population to be concentrated in the top $5 \mathrm{~m}$ throughout the winter in Saanich Inlet, British Columbia. In the Peru upwelling zone, $M$. rubrum has been shown to migrate vertically by as much as 30 to $40 \mathrm{~m}$, commencing at dawn and arriving at the surface by late morning (Smith \& Barber 1979, Sorokin 1979, Sorokin \& Kogelschatz 1979, Barber \& Smith 1981). This migration was monitored by Smith \& Barber (1979) as a dense band of chlorophyll, about $60 \mu \mathrm{g} \mathrm{l^{-1 }} \mathrm{Chl}$ a, while $10 \mathrm{~m}$ above and below this layer the chlorophyll concentration was $2 \mu \mathrm{g}^{-1}$. Chlorophyll concentrations did reach $1000 \mu \mathrm{g}$ $1^{-1}$ in a 10 to $20 \mathrm{~cm}$ thick layer (Smith \& Barber 1979). Dale (1987a) demonstrated that the abundance maximum of $M$. rubrum in Lindåspollene, Norway, underwent a diumal vertical migration from between 2 and $5 \mathrm{~m}$ depth during the day to $15 \mathrm{~m}$ at night. Vertical migration of $M$. rubrum has also been observed in Lindåspollene by Dale (1987b, 1988), and in New Zealand coastal waters by Mackenzie \& Gillespie (1986) and Mackenzie et al. (1986). In the North Sea, Baars \& Franz (1984) speculated that a diurnal fluctuation in surface chlorophyll could have been due to an internal rhythm of the symbiotic association in $M$. rubrum, which was abundant at the time. This fluctuation could equally have been caused by vertical migration of this species.

Given such distributions and migration, the depth intervals of bottle or pump sampling usually adopted in phytoplankton or microzooplankton studies (e.g. surface and 10 or $5 \mathrm{~m}$ intervals) could seriously underestimate the contribution of this species to the community. For instance Revelante \& Gilmartin (1987) found Mesodinium rubrum to be an important species in the Damariscotta Estuary, Gulf of Maine, but sampling with a water bottle at the surface, 7,15 , and $22 \mathrm{~m}$, could have significantly underestimated the population. Similarly, Montagnes \& Lynn (1989) and Stoecker et al. (1989) sampled at ca $10 \mathrm{~m}$ intervals during examinations of the role in productivity of $M$. rubrum in other regions of the Gulf of Maine.

Smith \& Barber (1979) suggested that the contribution to productivity of Mesodinium rubrum, even during blooms, could also be seriously underestimated, since at sea, samples for physiological rate incubations are often taken from the surface in the early morning before $M$. rubrum has completed its upward migration (see also Mackenzie et al. 1986). In situ fluorometry can overcome some of the problems of describing vertical distributions (e.g. Soulsby et al. 1984), but this can only be employed to give information on a single species during periods of total dominance, as encountered during blooms.

Some studies have taken integrated samples from 
pump intakes lowered over given depth ranges Although this could potentially give a more accurate estimation of the total population in the water column. the procedure is nevertheless subject to the limitations of pumping samples already described. The potentially distorting effect of sampling upon determinations of the vertical distribution of Mesodinium rubrum, cannot be overstated. During design of field sampling programs particular attention must be given to sample depth interval, time of day, and state of tide.

\section{Horizontal distribution}

The extremely inhomogenous horizontal distribution of Mesodinium rubrum is a further complication hindering sampling of this species. Blooms of $M$. rubrum have been noted to occur in irregular patches or clouds during calm conditions (Fenchel 1968, Packard et al. 1978), and aligned in streaks or 'windrows' when wind speed increases (Powers 1932, Packard et al. 1978). In a dynamic environment such as the Southampton Water estuary, streaks and patches of red-water caused by $M$. rubrum can be advected rapidly past the sampling station, on time and distance scales of seconds and metres respectively (Crawford pers. obs.). Clearly this presents considerable problems for representative sampling.

The potential of remotely sensed imagery for providing a more synoptic insight into the horizontal distribution and dynamics of blooms of Mesodinium rubrum appears impressive. In addition to providing some of the highest chlorophyll concentrations encountered in the marine environment, the cryptomonad endosymbiont of $M$. rubrum also possesses a red phycobiliprotein pigment, giving blooms their characteristic colour. Other than the cryptophyceae, this pigment is only found in the cyanophycean and rhodophycean classes of algae (White et al. 1977). Another pigment diagnostic of the cryptophyceae is alloxanthin, which has been detected by HPLC when $M$. rubrum is abundant in the North Sea (Gieskes \& Kraay 1983).

Considerable success has been achieved in detecting blooms of Mesodinium rubrum in British Columbian coastal waters, using the Fluorescence Line Imager (Lin et al. 1984) and, with more limited success in Southampton Water, using the 'Daedalus' airborne thematic mapper (Purdie et al. 1988). The resolution obtained by Purdie et al. (1988) was limited by the sparsity of seatruth measurements, which prohibited a statistically valid calibration of the spectral data set. However, more recent overflights using the same instrument (Purdie \& Garcia 1988) have mapped, in detail, changes in the distribution of a bloom of $M$. rubrum over part of the tidal cycle in the Southampton Water estuary. A bloom of $M$. rubrum in this estuary in July 1984 was also detected by satellite, through processing of Landsat TM data (Robinson \& Holligan 1987).

Although these preliminary remote sensing studies appear promising, difficulties associated with the vertical migration of motile phytoplankton, and particularly Mesodinium rubrum, must be considered. Diurnal migrations of 30 to $40 \mathrm{~m}$, such as those undertaken by $M$. rubrum in the ocean upwelling off Peru (Smith \& Barber 1979, Sorokin 1979, Sorokin \& Kogelschatz 1979, Barber \& Smith 1981), pose problems for the remote sensing of ocean colour, since this principally involves detection of integrated near surface colour. Because the blooms are only present close to the surface between about 11.00 and $15.00 \mathrm{~h}$, any remotely sensed data collected outside of this period may completely ignore a substantial proportion of the depth integrated chlorophyll. Although vertical migration of this species in coastal waters and estuaries is more limited (e.g. Soulsby et al. 1984, Dale 1987a), and may be complicated by tidal effects, the penetrating capabilities of detectors is also reduced in these more turbid environments, and difficulties resulting from migration may also be envisaged. Meaningful interpretation of remotely sensed images from areas susceptible to blooms of $M$. rubrum are limited without detailed knowledge of the local dynamics of migrations of this species.

\section{ENUMERATION}

\section{Live counting}

The technique of live counting is advocated by some (e.g. Sorokin 1981) to be the only reliable means of enumerating pelagic ciliates. However, movement itself can be a problem in the live observation of highly motile ciliates. Mesodinium rubrum is a particular problem since it alternates between periods of total motionlessness, and such explosive bursts of swimming activity that the direction of these is impossible to follow out of the field of view (Lindholm 1985). Various narcotizing agents have been successfully employed to immobilize $M$. rubrum, such as hydrogen peroxide (Bary \& Stuckey 1950), MS222 (Sandoz, Basel) (Lindholm 1978,1981), EDTA (ethylenediaminetetraacetate) and oxalic acid (Lindholm 1982) and droperiodol (Tumantseva 1985). Zaika \& Averina (1968) apparently used, to their advantage, the rheotactic swimming behaviour exhibited by $M$. rubrum and other ciliates, by adjusting the rate of gravitational flow of water through a capillary tube until just sufficient to counter the movement of the ciliates, which could then be enumerated.

An additional problem is that Mesodinium rubrum is 
so delicate that it often explodes under the microscope, due to thermal effects and possibly physical damage (Taylor et al. 1971, Lindholm 1985). Dale \& Burkill (1982) described an isothermal cell counting chamber in which ciliates can be enumerated in the live state and which overcomes the problem of thermal shock With this technique they demonstrated an improvement of up to $20 \%$ over counting of conventionally fixed pelagic ciliate species. However, numerical estimates of Mesodinium spp. were shown to be some $20 \%$ lower than those from fixed samples. This they attributed either to the difficulty in observation of the very small forms of this genus when motionless, or to misidentification and overestimation of poorly fixed specimens of other genera in the fixed counts. Alternatively, it may simply be that $M$. rubrum and other Mesodinium spp., being so extremely delicate, are particularly sensitive to handling or containment of any description. Thus, live counting is arguably not the optimum method of enumeration for this species. Additionally, in any sampling program, the time constraints involved with live counting have to be 'weighed' against the convenience of fixing samples and the subsequent increase in resolution of sampling spatial and temporal distributions, which are of such critical importance in abundance estimates of $M$. rubrum

\section{Fixation and preservation}

In common with the majority of naked ciliates (e.g. Sorokin 1981), the fixation and subsequent preservation of Mesodinium rubrum cells in a recognisable state is a major difficulty. This problem may be more serious for $M$. rubrum due to its structural weakness, probably resulting from the thin pellicle, reduced alveoli and high degree of internal vacuolation (Taylor et al. 1971. Hibberd 1977, Grain et al. 1982). M. rubrum has been noted not only to distort, as do other naked ciliates, but often to disintegrate or explode, both in commercial formalin (Taylor et al. 1971) and buffered formaldehyde (e.g. Ryther 1967, White et al. 1977, Sampayo \& Cabecadas 1981). Although Fonds \& Eisma (1967), Fenchel (1968), McAlice (1968) and Lindholm (1978) all found formaldehyde fixation adequate for counting cells during blooms, the relative fraction of cells that disintegrated is unknown. Moreover, positive identification of distorted cells under non-bloom conditions is much less certain. Thus the use of formaldehyde for routine microplankton counts must be considered questionable.

Several microplankton studies employing buffered formaldehyde as a fixative have noted numerous poorly fixed ciliate specimens, e.g. 'apparently not oligotrichs' (Beers \& Stewart 1971) and 'predominantly holotrichs' (Beers et al. 1975). Beers \& Stewart (1971) suggested that in their category of 'other ciliates (other, that is, than sheathed or unsheathed oligotrichs), which included the holotrichs Mesodinium sp. and Didinium sp., almost $40 \%$ of specimens were of questionable identification due to poor fixation. Jimenez \& Intriago (1987) have commented on the lack of records of Mesodinium rubrum in phytoplankton counts in the eastern Pacific, caused by the use of 'formalin solution' as a routine fixative. Several studies recording $M$. rubrum as common have used buffered formaldehyde as a fixative and may be regarded as potential underestimates (e.g. Reid et al. 1978, Cullen et al. 1982).

The use of formaldehyde in fixation and enumeration of Mesodinium rubrum can be improved to some extent by combination with epifluorescence microscopy, with which the characteristic orange-red autofluorescence of the phycoerythrin pigment is apparent. This was utilised effectively by McManus \& Fuhrmann (1986), Sherr et al. (1986), and Stoecker et al. (1989), all of whom recorded $M$. rubrum as abundant.

Lugol's iodine appears to be a rather more reliable routine fixative for Mesodinium rubrum (Jimenez \& Intriago 1987. Crawford pers. obs.), and has been experimentally established to preserve non-loricate ciliates better than buffered formaldehyde, which caused 30 to $70 \%$ loss of these forms (Revelante \& Gilmartin 1983). Taylor et al. (1971) also noted cells to remain intact in Lugol's iodine, though with a serious disorganisation of the cirri and ciliary belt. Several recent studies employing Lugol's iodine as a fixative have recorded $M$. rubrum as an important component of the plankton (e.g. Gieskes \& Kraay 1983, Revelante \& Gilmartin 1983, 1987, Andersen \& Sørensen 1986, Kivi 1986, Leppänen \& Bruun 1986). Some caution should be excercised in the use of Lugol's iodine however, since Crawford (unpubl.) has preliminary evidence of a sensitivity in the fixation of $M$. rubrum cells to the concentration of Lugol's adopted. The weakest solutions (e.g. Kimor 1976) result in up to $100 \%$ cell lysis. This is unfortunate, since guidelines in the literature for the concentration and quantity of Lugol's iodine required are rather vague, and can vary by at least an order of magnitude (e.g. contrast recommendations by Kimor 1976 with those of Throndsen 1978a). At least until adequate comparisons have been undertaken, the stronger acid version (e.g. Throndsen 1978a) is recommended (100 g KI, $50 \mathrm{~g}$ iodine, $100 \mathrm{ml}$ glacial acetic acid, 11 distilled water), in a ratio of 100:1 (sample:fixative).

A number of other fixatives have been utilized in cytological studies on Mesodinium rubrum such as Bouin's solution (Powers 1932, White et al. 1977), Schaudinn's fluid (Powers 1932, Bary \& Stuckey 1950) 
and, more commonly, buffered glutaraldehyde (Taylor et al. 1969, 1971, Hibberd 1977, Oakley \& Taylor 1978, Grain et al. 1982, Lindholm et al. 1988). Sampayo \& Cabecadas (1981) and Cabecadas et al. (1983) found glutaraldehyde better than either formaldehyde or Lugol's iodine for routine fixation of $M$. rubrum. White et al. (1977) tried a range of fixatives on samples from a bloom of $M$. rubrum; the best results were obtained using osmium tetroxide. However, none of these studies gave any indication of the fraction of disintegrated cells. Moreover, the use of these fixatives for routine counts is normally precluded by their cost, their toxicity, and their more complex method of application (Kimor 1976).

For preservation of the characteristic pattern of cilia and cirri of living Mesodinium rubrum cells, the only fixative successfully employed to date has been Parducz's fixative (Parducz 1966), which was utilized extensively for light microscopy in the comprehensive study by Taylor et al. (1971).

The simplest and most reliable fixative to date for Mesodinium rubrum appears to be Lugol's iodine, though this may cause problems in its acid form for other groups such as coccolithophorids (Kimor 1976 , Throndsen 1978a) and loricate oligotrichs (Dale \& Dahl 1987). Recent developments with protargol staining after Bouin's fixation (Montagnes \& Lynn 1987) appears promising for the study of $M$. rubrum (Montagnes \& Lynn 1989) and ciliates generally (Montagnes et al. 1988a).

\section{Future perspectives}

Any form of enumeration that necessitates removal of microplankton samples from their environment, must introduce at least some bias and probably damages the more delicate forms. Perhaps the most valuable means of sampling fragile microplankton would be an in situ, non-destructive, perhaps photographic, type of detector. The only development in this direction has been that of Beers et al. (1970), who described the use of holography for providing a permanent record of the contents of settling chambers for the inverted microscope. However, this system was restricted in resolution to the larger phytoplankton ( $>30 \mu \mathrm{m})$, and worked only in 1 plane. Beers (1978c) suggested that future developments in laser holography could theoretically provide the potential for 3-dimensional permanent records of the total size spectrum of phytoplankton, avoiding both concentration and fixation of samples. Whether these developments could be incorporated into an in situ device seems a question unlikely to be resolved in the foreseeable future, since no known recent progress has continued in this field.

\section{PHYSIOLOGICAL MEASUREMENTS}

\section{Sub-sampling}

The behaviour and fragility of Mesodinium rubrum present experimental problems whenever this species is relatively abundant. Any subsampling for experimental purposes must take account of the extreme rapidity of aggregation, both in response to light and local currents (see Taylor et al. 1971, Lindholm 1985). This aggregation can be observed in bucket samples from dense blooms (Lindholm 1985, Crawford pers. obs.). Any sample to be divided which has stood for more than a few seconds, should be gently though thoroughly mixed, whilst avoiding severe agitation which may cause damage or lysis of cells. Ignorance of these procedures may lead to accumulation of cells in a sample being subsampled (Cabecadas et al. 1983), and poor replication of cell counts between subsamples (Crawford pers. obs.).

\section{Productivity}

The few studies to date which have examined the photosynthetic rate of Mesodinium rubrum, suggest this species to be exceptionally productive (Packard et al. 1978, Smith \& Barber 1979, Cabecadas et al. 1983). Not only is the assimilation number $\left(\mathrm{P}_{\mathrm{m}}^{\mathrm{B}}\right)$ high and photoinhibition ( $\beta$ ) apparently minimal (Smith \& Barber 1979, Harrison et al. 1981, Platt et al. 1980), but the initial slope of the photosynthesis/irradiance (P/I) curve $(\alpha)$, a measure of photosynthetic efficiency at low light levels, appears comparable at least during blooms to that of the diatoms (Platt et al. 1980, Harrison et al. 1981).

This remarkable photosynthetic capacity, coupled with the elevated biomass levels encountered during blooms (see Lindholm 1985), is not without its drawbacks. For instance, Packard et al. (1978) and Smith \& Barber (1979) have shown depressed photosynthesis in longer incubations of Mesodinium rubrum samples from blooms, compared to shorter ones, resulting either from lysis of cells or nutrient exhaustion. Smith \& Barber (1979) estimated that incubations of these samples for more than $1 \mathrm{~h}$, would result in nutrient exhaustion, since the level of inorganic nitrogen was $12.1 \mathrm{ug}$-at. $\mathrm{N} \mathrm{I}^{-1}$ at the start of the incubation, whilst the calculated nitrogen demand of the samples was $15.5 \mu \mathrm{g}$-at. $\mathrm{N} \mathrm{I}^{-1} \mathrm{~h}^{-1}$. Dugdale et al. (1987) actually measured a nitrate uptake rate of $5 \mu \mathrm{g}$-at. $\mathrm{N}^{-1} \mathrm{~h}^{-1}$ in samples from blooms of $M$. rubrum, thus supporting the contention that nutrients may be limiting during longer incubations.

Lysis of cells during containment, mentioned by Smith \& Barber (1979), may be a general problem in physiological studies of microplankton (e.g. Venrick et 
al. 1977), though Mesodinium rubrum is probably particularly susceptible. Rupture of cells upon filtration is a further difficulty particularly for ${ }^{14} \mathrm{C}$ estimates of productivity After gentle filtration, Smith \& Barber (1979) were able to reject filters on the basis of red/pink pigment colouration to the edges, as an indication of mass lysis of cells. However, lysis on a smaller scale or rupture of cells during incubations at lower cell densities would be undetectable. Considerable distortion of physiological parameters could result when $M$. rubrum is abundant. In particular, this may cause underestimation of particulate production and consequential overestimation of dissolved excretion products in ${ }^{14} \mathrm{C}$ incubations. The red colouration to filters and elevation of extracellular excretion products has been noted by Sellner (1981) in blooms of $M$. rubrum off the coast of Peru. Throndsen (1978b) observed mass rupture of $M$. rubrum upon addition of slightly hypotonic rinsing water to fractionation screens. This resulted in overestimation of the ${ }^{14} \mathrm{C}$ productivity estimate for the $<5 \mu \mathrm{m}$ fraction, caused by symbionts of $M$. rubrum (accounting for $54 \%$ of productivity) passing through this screen.

A major limitation in the physiological studies on Mesodinium rubrum to date, has been the presence of other phytoplankton taxa and micro-organisms, even during major blooms. Single species techniques or pure cultures are now required to determine physiological properties of $M$. rubrum under controlled conditions. Stoecker et al. (1989) have provided the first such data through isolation of cells of $M$. rubrum. Using the ${ }^{14} \mathrm{C}$ technique, Stoecker et al. (1989) established a photosynthetic rate of $85 \mathrm{pg} \mathrm{C}$ cell ${ }^{-1} \mathrm{~h}^{-1}$ for $M$. rubrum, at an irradiance of $100 \mu \mathrm{E} \mathrm{m}^{-2} \mathrm{~s}^{-1}$. The prospects for establishment of pure cultures is remote however, since no known author has maintained cells of $M$. rubrum in the laboratory for an extended period (Taylor et al. 1971, Lindholm 1985).

\section{Respiration}

The respiration rate of Mesodinium rubrum is of particular interest in view of its motile capabilities, but has received little detailed attention. Although Margalef et al. (1979) speculated that $M$. rubrum probably allocates more energy to swimming than to reproduction, the studies to date (Packard et al. 1978, Setchel et al. 1978, Smith \& Barber 1979) suggest the respiration rate to be rather low and within the range of conventional phytoplankton. This is perhaps not surprising in view of the claim by Fenchel \& Finlay (1983) that motility in protozoa accounts for an insignificant fraction of the respiration rate. However, it should be noted that $M$. rubrum can swim at over $5 \mathrm{~mm} \mathrm{~s}^{-1}$ (Lindholm 1985), an order of magnitude faster than the majority of dinoflagellates (Smith \& Barber 1979), and some 5 times quicker than most ciliates. Therefore, a more significant fraction could be anticipated for this species which, one could speculate, may not necessarily be swimming in incubation bottles. Should motility account for a significant proportion of the metabolic rate in $M$. rubrum, this may have important implications, not only for measurements of respiration rate, but also for determinations of photosynthetic rate. Smith \& Barber (1979) noted cessation of swimming activity by M. rubrum at optimum light levels, thus distortions of P/I curves may result, since conventional techniques of photosynthesis determination assume a constant respiration rate. Clearly, the respiration rate of $M$. rubrum has aroused considerable speculation both in this paper and elsewhere, and deserves more detailed examination using single species techniques or pure cultures.

\section{RECENT ESTIMATES OF ABUNDANCE}

Although Taylor et al. (1971) commented upon the extremely widespread geographical distribution of Mesodinium rubrum, it has only recently become apparent how abundant this species may be. A preoccupation with bloom studies, in addition to the difficulties described in this paper, may have diverted attention from the potential role of $M$. rubrum as a regular component of the phytoplankton.

Mesodinium rubrum has often been noted to be the dominant member of the protozoan plankton during certain periods of the year (e.g. Michanek 1965, Eriksson et al. 1977, Takahashi \& Hoskins 1978, Revelante \& Gilmartin 1983, Mamaeva 1985, Andersen \& Sorensen 1986, Leppänen \& Bruun 1986). Ironically though, only a few recent studies minimizing some of the problems involved, have conceded its potential contribution to primary productivity (Reid et al. 1978, Grice et al. 1980, Rcvelante \& Gilmartin 1983, 1987, Leppänen \& Bruun 1986, Mackenzie \& Gillespie 1986, Mackenzie et al. 1986, Stoecker et al. 1989).

Table 1 summarizes some recent studies which have attempted to quantify the contribution of Mesodinium rubrum to microplankton biomass or productivity.

In British Columbian waters near Vancouver, Mesodinium rubrum is often recorded during blooms (Taylor et al. 1969, 1971, Oakley \& Taylor 1978) and was commonly encountered during many of the 'CEPEX' enclosure studies (Takahashi et al. 1975, Beers et al. 1977a,b, Parsons et al. 1977, Grice et al. 1980). The significance of $M$. rubrum in this area was further emphasised by Takahashi \& Hoskins (1978), who, during winter months, demonstrated $M$. rubrum to represent 43 to $85 \%$ of the microzooplankton carbon biomass, an order of magnitude greater abundance than 
Table 1 Mesodinium rubrum. Some recent estimates of its contribution to microplankton biomass or productivity in marine ecosystems

\begin{tabular}{|c|c|c|c|}
\hline Location & Period & Contribution of $M$. rubrum & Source \\
\hline $\begin{array}{l}\text { Saanich Inlet. } \\
\text { British Columbia }\end{array}$ & Dec 1975-Feb 1976 & $\begin{array}{l}43-85 \% \text { protozoan carbon biomass, } \\
\text { an order of magnitude greater than } \\
\text { other species. Averaged about } 8 \% \\
\text { phytoplankton biomass between } \\
0 \text { and } 10 \mathrm{~m}\end{array}$ & Takahashi \& Hoskins (1.978) \\
\hline $\begin{array}{l}\text { Saanich Inlet, } \\
\text { British Columbia } \\
\text { (CEPEX unmixed } \\
\text { enclosure) }\end{array}$ & Summer 1978 & $\begin{array}{l}\text { Biomass peaked at } 15 \mu \mathrm{g} \mathrm{Cl} \mathrm{I}^{-1} \\
\text { throughout water column; } 13 \% \text { aver- } \\
\text { age phytoplankton carbon; } 205 \% \\
\text { average heterotrophic ciliate carbon. } \\
\text { Significantly less in mixed enclosure }\end{array}$ & Grice et al. (1980) \\
\hline Adriatic Sea & $\begin{array}{l}\text { Summer and Winter } \\
1978-1982\end{array}$ & $\begin{array}{l}\text { Averaged } 173 \% \text { total microzooplank- } \\
\text { ton numerically, and } 40 \% \text { biomass } \\
\text { throughout water column, under } \\
\text { stratified conditions. Not present } \\
\text { under well-mixed conditions }\end{array}$ & Revelante \& Gilmartin (1983) \\
\hline Baltic Sea & Mar-Jun 1982 & $\begin{array}{l}\text { Ca } 10 \% \text { total phytoplankton } \\
\text { production, and } 2 \% \text { biomass }\end{array}$ & Leppänen \& Bruun (1986) \\
\hline $\begin{array}{l}\text { Damariscotta Estuary, } \\
\text { Gulf of Maine }\end{array}$ & Mar 1981-Jun 1982 & $\begin{array}{l}\text { Within order of } 100 \% \text { (from their } \\
\text { Figs. } 3 \text { and } 8 \text { ) of total microzooplank- } \\
\text { ton biomass between Dec and Apr } \\
\text { Sporadic occurrence during the rest } \\
\text { of the year }\end{array}$ & Revelante \& Gilmartin (1987) \\
\hline $\begin{array}{l}\text { Georges Bank, } \\
\text { Gulf of Maine }\end{array}$ & Summer 1987 & $\begin{array}{l}\text { M. rubrum \& Laboea strobila (approx. } \\
\text { equal) contributed } 1 \text { to } 7 \% \text { total phy- } \\
\text { toplankton carbon fixed, and } 14 \text { to } \\
90 \% \text { microplankton carbon fixed. } \\
\text { M. rubrum numerically } 30 \% \text { of total } \\
\text { ciliates at shallower stations, and } 3 \% \\
\text { at deeper stations off the bank }\end{array}$ & Stoecker et al. (1989) \\
\hline $\begin{array}{l}\text { Isles of Shoals, } \\
\text { Gulf of Maine }\end{array}$ & May 1985-Aug 1986 & $\begin{array}{l}\text { Ca } 0.3 \% \text { annual phytoplankton } \\
\text { production }\end{array}$ & Montagnes \& Lynn (1989) \\
\hline
\end{tabular}

any other species, and around $8 \%$ phytoplankton biomass (between 0 and $10 \mathrm{~m}$ ). In a 'CEPEX' enclosure study in the same area in summer, Grice et al. (1980) suggested that it constituted, at its peak abundance, about $13 \%$ of the phytoplankton carbon in an unmixed enclosure.

Revelante \& Gilmartin (1983) have shown that the numerical abundance of Mesodinium rubrum exceeded that of all the microzooplankton, under stratified conditions in the Adriatic Sea, and commented upon its potential importance as a primary producer.

Reports from the Baltic Sea have suggested Mesodinium rubrum to be a very significant species (e.g. Michanek 1965, Eriksson et al. 1977, Lindholm 1981. Smetacek 1981. Mamaeva 1985, Kivi 1986). During spring in the open northern Baltic, Leppänen \& Bruun (1986) have estimated the contribution of $M$. rubrum, the dominant ciliate species, to be $10 \%$ of the total primary productivity, and suggest this value may be even greater closer to the coast. However, this estimate was determined indirectly from production equations derived for other species and may, or may not, be appropriate for $M$. rubrum.

There are few records of Mesodinium rubrum from the North Sea other than the report of a bloom by Fonds \& Eisma (1967). However, observations in some areas suggest it is sufficiently abundant, at least during May, to dominate surface chlorophyll (Gieskes \& Kraay 1983, Baars \& Franz 1984, Crawford pers. obs.).

In upwelling areas where Mesodinium rubrum forms massive blooms (Ryther 1967, Barber et al, 1969, Packard et al. 1978, Smith \& Barber 1979, Sorokin 1979, Sorokin \& Kogelschatz 1979), little is known of its occurrence at other times, other than brief mentions in a few studies (e.g. Beers et al. 1971, Blasco et al. 1980, 1981). However, Jimenez \& Intriago (1987) have recently discussed the potential role of both bloom and pre-bloom levels of $M$. rubrum in the upwelling off Ecuador

Several recent studies have examined the role of Mesodinium rubrum in different locations within the Gulf of Maine, USA. Revelante \& Gilmartin (1987) found it to be a dominant ciliate in winter in the 
Damariscotta Estuary, Gulf of Maine, and thus a potentially important phototroph. Montagnes \& Lynn (1989) provided the first assessment of the annual contribution to productivity made by $M$. rubrum, in a study off the Isles of Shoals, Maine. The annual contribution was suggested to be only $0.3 \%$ of phytoplankton production. However, as in the study by Leppänen \& Bruun (1986), this was based on a rather indirect method of estimating production for heterotrophic ciliates, and may be inappropriate for $M$. rubrum. The study by Stoecker et al. (1989), during summer on the Georges Bank, Gulf of Maine, adopted the more objective method of comparing ${ }^{14} \mathrm{C}$ production estimates of isolated $M$. rubrum cells with those of intact water samples. They suggested that the photosynthetic ciliates $M$ rubrum and Laboea strobila, together contributed (approximately equal) 1 to $7 \%$ total phytoplankton carbon fixed at stations on the bank.

Clearly, the quantity of useful non-bloom data presented to date is insufficient to determine the true role of Mesodinium rubrum in marine ecosystems, and precludes an assessment of whether its abundance has increased in recent years in response to coastal eutrophication. However, many reports do suggest it to be an important member of the phytoplankton, at least during certain periods of the year. In view of its potential contribution, considerably more research effort should be devoted to assessing its abundance and investigating its physiology, ecology, and taxonomy. Moreover, it must still be concluded, in agreement with Smith \& Barber (1979), that the contribution of this enigmatic phototroph to the productivity of coastal, estuarine, and upwelling ecosystems has been seriously underestimated.

Acknowledgements. I would like to thank Dr D. A. Purdie, Professors A. P. M. Lockwood and M. A. Sleigh, for their encouragement and helpful critical reading of earlier drafts of the manuscript. I am indebted to Drs D. K. Stoecker, T Lindholm, and 2 anonymous referees for the criticisms which shaped the final form of the manuscript. This paper was conceived as a result of N.E.R.C. grant no. GR3/5683

\section{LITERATURE CITED}

Andersen, P., Sørensen, H. M. (1986). Population dynamics and trophic coupling in pelagic microorganisms in eutrophic coastal waters. Mar. Ecol. Prog. Ser. 33: 99-109

Baars, M. A., Franz, H. G. (1984). Grazing pressure of copepods on the phytoplankton stock of the central North Sea. Neth. J. Sea Res. 18: 120-142

Bakker, C. (1966). Een protozo in symbiose met algen in het Veerse Meer. De Levende Natuur 69: 180-187

Bakker, C. (1967a). Massale ontwikkeling van ciliaten met symbiontische algen in het Veerse Meer De Levende Natuur 70: 166-173

Bakker, C. (1967b). Veranderingen in milieu en plankton van het Oosterscheldegebied. Vakbl. Biol. 47: 181-192
Barber, R. T., Smith, W. O. (1981). The role of circulation, sinking and vertical migration in physical sorting of phytoplankton in the upwelling centre at ${ }^{15} \mathrm{C}$. In: Richards, F. A. (ed.) Coastal Upwelling: Coastal and Estuarine Sciences 1 Geophysical Monography Bd., Washington D.C., p. $366-371$

Barber, R. T., White, A. W., Siegelman, H. W. (1969). Evidence for a cryptomonad symbiont in the ciliate, Cyclotrichium meunieri. J. Phycol. 5: 86-88

Barlow, J. P., Monteiro, J. D. C. (1979). Selective grazing by zooplankton populations in Southampton Water, England U.K. Mar Biol. 53: 335-344

Bary, B. M., Stuckey, R. G. (1950). An occurrence in Wellington Harbour of Cyclotrichium meunieri Powers, a ciliate causing red water, with some additions to its morphology. Trans. R. Soc. N.Z. 78: 86-92

Beers, J. R. (1978a). Pump sampling. In: Sournia, A. (ed.) Phytoplankton manual. Monographs on oceanographic methodology 6. Unesco Press, Paris, p. 41-49

Beers, J. R. (1978b). About microzooplankton. In: Sournia, A. (ed.) Phytoplankton manual. Monographs on oceanographic methodology 6. Unesco Press, Paris, p. 288-296

Beers, J. R. (1978c). Perspectives on holography. In: Sournia, A. (ed.) Phytoplankton manual. Monographs on oceanographic methodology 6. Unesco Press, Paris, p. 123

Beers, J. R., Knox, C., Strickland, J. D. H. (1970). A permanent record of plankton samples using holography. Limnol. Oceanogr 15: 967-970

Beers, J. R., Reeve, M. R., Grice, G. D. (1977a). Controlled ecosystem pollution experiment: effect of mercury on enclosed water columns. IV Zooplankton population dynamics and production. Mar Sci. Communs 3: 355-394

Beers, J. R., Reid, F. M. H., Stewart, G. L. (1975). Microplankton of the North Pacific central gyre. Population stucture and abundance, June 1973. Int. Revue ges. Hydrobiol. 60: $607-638$

Beers, J. R., Reid, F. M. H., Stewart, G. L. (1980). Microplankton population structure in southern Californian nearshore waters in late spring. Mar Biol. 60: 209-226

Beers, J. R., Stewart, G. L. (1967). Microzooplankton in the euphotic zone at five locations across the California current. J. Fish. Res. Bd Can. 24: 2053-2068

Beers, J. R., Stewart, G. L. (1969a). The vertical distribution of microzooplankton and some ecological observations. J. Cons. perm. int Explor. Mer 33: 30-44

Beers, J. R., Stewart, G. L. (1969b). Microzooplankton and its abundance relative to the larger zooplankton and other seston components. Mar Biol. 4: 182-189

Beers, J. R., Stewart, G. L. (1970). Numerical abundance and estimated biomass of microzooplankton. In: Strickland, J. D. H. (ed.) The ecology of the plankton off La Jolla, California, in the period April through September, 1967. Bull. Scripps Instn Oceanogr. (New Ser.) 17:67-87

Beers, J. R., Stewart, G. L. (1971). Microzooplankters in the plankton communities of the upper waters of the eastern tropical Pacific. Deep Sea Res. 18: 861-883

Beers, J. R., Stewart, G. L., Hoskins, K. D. (1977b). Dynamics of microzooplankton populations treated with copper: controlled ecosystem pollution experiment. Bull. mar. Sci. 27: $66-79$

Beers, J. R., Stewart, G. L., Strickland, J. D. H. (1967). A pumping system for sampling small plankton. J. Fish. Res. Bd Can 24: 1811-1818

Beers, J. R., Stevenson, M. R., Eppley, R. W., Brooks, E. R. (1971). Plankton populations and upwelling off the coast of Peru, June 1969. Fish. Bull. U.S. 69: 859-876

Blackbourn, D. J., Taylor, F. J. R., Blackbourn, J. (1973). 
Foreign organelle retention by ciliates. J. Protozool. 20 : 286-288

Blasco, D., Estrada, M., Jones, B. (1980). Phytoplankton distribution and composition in the northwest African upwelling near Cabo Corbeiro. Deep Sea Res. 27: 799-821

Blasco, D., Estrada, M., Jones, B. (1981). Short time variability of phytoplankton populations in upwelling regions - the example of N.W Africa. In: Richards, F. A. (ed.) Coastal Upwelling: Coastal and Estuarine Sciences 1. Geophysical Monography Bd., Washington D.C., p. 339-347

Burkholder, P. R., Burkholder, L. M., Almodovar, L. R. (1967). Carbon assimilation of marine flagellate blooms in neritic waters of southern Puerto Rico. Bull. mar Sci. 17. 1-15

Burkill, P. H. (1982). Ciliates and other microplankton components of a nearshore food-web: standing stocks and production processes. Annls. Inst. océanogr., Paris, Fasc. Suppl. 58: 335-350

Cabecadas, G., Cunha, M. E., Moita, M. T Pissarra, J., Sampayo, M. A. de M. (1983). Red tide in Cascais Bay, Portugal. Bol. Inst. Nac. Invest. Pescas, Lisboa 10: 81-123

Chester, A. J. (1978). Microzooplankton relative to a subsurface chlorophyll maximum layer. Mar. Sci. Communs 4: 275-292

Cloern, J. E., Cole, B. E., Wong, R. L. J., Alpine, A. E. (1985). Temporal dynamics of estuarine phytoplankton: a case study of San Francisco Bay. Hydrobiologia 129: 153-176

Cullen, J. J., Reid, F. M. H., Stewart, E. (1982). Phytoplankton in the surface and chlorophyll maximum off southern California in August, 1978. J. Plankton Res. 4: 665-695

Dale, T (1987a). Diel vertical distribution of planktonic ciliates in Lindåspollene, western Norway. Mar. microb. Fd Webs 2: $15-28$

Dale, T (1987b). Oil pollution and plankton dynamics. II Abundance pattern of ciliates inside and outside enclosures and the responses of ciliates to oil during the 1980 spring bloom in Lindaspollene, Norway. Sarsia 72: $197-202$

Dale, T (1988). Oil pollution and plankton dynamics. V Controlled ecosystem pollution experiments in Lindâspollene. Norway, June 1980: effects of oil, oil/nutrients, and oil/ dispersant on microplankton. Sarsia 73: 169-178

Dale, T., Burkill, P. H. (1982). Live counting - a quick and simple technique for enumerating pelagic ciliates. Annls Inst. océanogr., Paris, Fasc. Suppl. 58: 267-276

Dale, T., DahI, E. (1987). Mass occurrence of planktonic oligotrichous ciliates in a bay in southern Norway. J. Plankton Res. 9: 871-879

De Sousa Lima, H., Williams, P. J. LeB. (1978). Oxygen consumption by the planktonic population of an estuary Southampton Water. Est. cstl mar. Sci. 6: 515-523

Dugdale, R. C., Wilkerson, F. P., Barber, R. T., Blasco, D., Packard, T T (1987). Changes in nutrients, $\mathrm{pH}_{\text {, light }}$ penetration and heat budget by migrating photosynthetic organisms. Oceanol. Acta Special Issue No. 6: 103-107

Elmgren, R. (1984). Trophic dynamics in the enclosed, brackish Baltic Sea. Rapp. P.v. Réun. Cons. perm. int. Expior Mer 183: 152-169

Eppley, R. W., Reid, F. M. H., Strickland, J. D. H. (1970). Estimates of phytoplankton crop size, growth rate and primary production. In: Strickland, J. D. H. (ed.) The ecology of the plankton off La Jolla. California, in the period April through September, 1967. Bull. Scripps Instn Oceanogr. (New Ser.) 17: 33-42

Eriksson, S., Sellei, C., Wallström, K. (1977). The structure of the plankton community of the Oregrundsgrepen (southwest Bothnian Sea). Helgoländer wiss. Meeresunters. 30: $582-597$
Fenchel. T. (1968). On 'red-water' in the Isefjord (inner Danish waters) caused by the ciliate Mesodinium rubrum. Ophelia 5: $245-253$

Fenchel, T., Finlay, B. J. (1983). Respiration rates in heterotrophic, free-living protozoa. Microb. Ecol. 9: 99-122

Fonds, M., Eisma, D. (1967). Upwelling water as a possible causn of red plankton bloom along the Dutch coast. Neth. J. Seu Res 3: 458-463

Gieskes, W. W. C., Kraay, G. W. (1983). Dominance of Cryptophyceae during the phytoplankton Spring bloom in the central North Sea detected by HPLC analysis of pigments. Mar. Biol. 75: 179-185

Goodmann, D., Eppley, R. W., Reid, F. M. H. (1984). Summer phytoplankton assemblages and their environmental correlates in the southern California Bight. J. mar. Res. 42: 1019-1049

Grain, J., Puytorac, P. de, Grolière, C. A. (1982). Quelques précisions sur l'ultrastructure et la position systématique du cilié Mesodinium rubrum, et sur la constitution des symbiontes chloroplastiques. Protistologica 18: 7-21

Grice, G. D., Harris, R. P., Reeve, M. R., Heinbokel, J. F., Davis, C. O. (1980). Large-scale enclosed water-column ecosystems. An overview of foodweb I, the final CEPEX experiment. J. mar. biol. Ass. U.K. 60; 401-414

Harrison, W. G., Platt, T., Calienes, R., Ochoa, N. (1981). Photosynthetic parameters and primary production of phytoplankton populations off the northern coast of Peru. In: Richards, F. A. (ed.) Coastal Upwelling: Coastal and Estuarine Sciences 1. Geophysical Monography Bd. Washington D.C., p. 303-311

Hellebust, J. A. (1970). The uptake and utilization of organic substances by marine phytoplankters. In: Hood, D. W. (ed.) Organic Matter in Natural Waters. University of Alaska, p. 225-256

Hibberd, D. J. (1977). Ultrastructure of the cryptomonad endosymbiont of the red-water ciliate Mesodinium rubrum. J. mar. biol. Ass. U.K. 57: 45-61

Holligan, P. M., Balch, W. M., Yentch, C. M. (1984). The significance of subsurface chlorophyll, nitrate and ammonium maxima in relation to nitrogen for phytoplankton growth in the stratified waters of the Gulf of Maine. J. mar. Res. 42: 1051-1073

Holm-Hansen, O., Taylor, F. J. R., Barsdate, R. J. (1970). A ciliate red-tide at Barrow, Alaska. Mar. Biol. 7: 37-46

Jimenez, R., Intriago, P. (1987). Observations on blooms of Mesodinium rubrum in the upwelling area off Ecuador Oceanol. Acta Special Issue No. 6: 145-154

Jonsson, P. R. (1987). Photosynthetic assimilation of inorganic carbon in marine oligotrich ciliates (Ciliophora, Oligotrichinal. Mar microb. Fd Webs 2: 55-68

Kahl, A. (1930-1935). Urtiere oder Protozod. I. Wimpertiere ocler Ciliata (Infusorial, eine Bearbeitung der freilebenden und ectocommensalen Infusorine der Erde, unter Ausschluss der marinen Tintinnidae. In: Dahl, F. (ed.) Die Tierwelt Deutschlands, vol. 18 (1930), vol. 21 (1931), vol. 25 (1932), vol. 30 (1935). Gustav Fischer, Jena, p. 1-886

Kimor, B. (1976). The fixation and preservation of marine protozoa: some problems and general considerations. In: Steedmann, H. F. (ed.) Zooplankton fixation and preservation. Monographs on oceanographic methodology 4. Unesco Press, Paris, p. 231-235

Kivi, K. (1986). Annual succession of pelagic protozoans and rotifers in the Tvärminne Storfjärden, SW coast of Finland. Ophelia, Suppl. 4: 101-110

Lackey, J. B. (1967). The microbiota of estuaries and their roles. In: Lauff, G. (ed.) Estuaries. AAAS. Washington, D.C., p. 291-302 
Lackey, J. B., Glendinning, K. A. (1963). A possible fish-killing yellow tide in Californian waters. Q. J Fla Acad. Sci. 26: $263-268$

Lackey, J. B., Glendinning, K. A. (1965). Ecology of the microbiota of San Diego Bay, California. Trans. S. Diego Soc. nat. Hist. 14: 9-40

Laval-Peuto, M., Rassoulzadegan, F. (1988). Autofluorescence of marine planktonic Oligotruchina and other ciliates. Hydrobiologia 159: 99-110

Laval-Peuto, M., Salvano, P., Gayol, P., Greuet, C. (1986). Mixotrophy in marine planktonic ciliates: ultrastructural study of Tontonia appendiculariformis (Ciliophora, Oligotrichida). Mar. microb. Fd Webs 1 81-104

Leegard, C. (1920). Microplankton from the Finnish waters during the month of May 1912. Acta Soc. Sci. fenn. 48: $1-45$

Leppänen, J. M., Bruun, J. E. (1986). The role of pelagic ciliates including the autotrophic Mesodinium rubrum during the spring bloom of 1982 in the open northern Baltic Sea proper. Ophelia, Suppl. 4: 147-149

Lin, S., Borstad, G. A., Gower, J. F. R. (1984). Remote sensing in the red spectral region. In: Nihoul, J. C. J. (ed.) Remote Sensing of Shelf Sea Hydrodynamics. Elsevier, Amsterdam, p. 317-336

Lindholm, T (1978). Autumnal mass development of the 'redwater' ciliate Mesodinium rubrum in the Aland archipelago. Mem. Soc. Fauna Flora fenn. 54: 1-5

Lindholm, T (1981). On the ecology of Mesodinium rubrum (Lohmann) (Ciliata) in a stagnant brackish basin on Aland, SW Finland. Kieler Meeresforsch., Sonderh. 5: 117-123

Lindholm, T. (1982). EDTA and oxalic acid - two useful agents for narcotizing fragile and rapid microzooplankton. Hydrobiologia 86: 297-298

Lindholm, T. (1985). Mesodinium rubrum - a unique photosynthetic ciliate. Adv, aquat. Microbiol. 3: 1-48

Lindholm, T., Lindroos, P., Mörk, A. C. (1988). Ultrastructure of the photosynthetic ciliate Mesodinium rubrum. Biosystems (Amsterdam) 21: 141-149

Lindholm, T., Mörk, A. C. (1989). Symbiotic algae and plastids in planktonic ciliates. Mem. Soc. Fauna Flora fenn. 65: in press

Lohmann, H. (1908). Untersuchungen zur Feststellung des vollständigen Gehaltes des Meeres an Plankton. Wiss Meeresunters. 10: 129-370

Mackenzie, A. L., Gillespie, P. A. (1986). Plankton ecology and productivity, nutrient chemistry, and hydrography of Tasman Bay, New Zealand, 1982-1984. N.Z.J, mar Freshwat. Res. 20: 365-395

Mackenzie, A. L., Kaspar, H. F., Gillespie, P. A. (1986). Some observations on phytoplankton species composition, biomass, and productivity in Kenepuru Sound, New Zealand, 1982-83. N.Z.J. Mar. Freshwat. Res. 20: 397-405

Mamaeva, N. V (1985). Infusorians as a component of the planktonic community in the Baltic Sea. Dokl. Biol. Sci. 281. 200-201

Margalef, R. (1967). The food web in the pelagic environment. Helgoländer wiss. Meeresunters. 15: 548-559

Margalef, R., Estrada, M., Blasco, D. (1979). Functional morphology of organisms involved in red tides, as adapted to decaying turbulence. In: Taylor, D. L., Seliger, H. H. (eds.) Toxic Dinoflagellate Blooms. Proc. 2nd. Int. Conf. Elsevier North Holland, Inc. Amsterdam, p. 89-94

McAlice, B. J. (1968). An occurrence of ciliate red-water in the Gulf of Maine. J. Fish. Res. Bd Can. 25: 1749-1751

McManus, G. B., Fuhrmann, J. A. (1986). Photosynthetic pigments in the ciliate Laboea strobila from Long Island Sound, USA. J. Plankton Res. 8: 317-327
Michanek, G. (1965). Zooplankton of the Baltic-observations on some smaller species. Botanica Gothoburg 3: 157-160

Montagnes, D. J. S., Lynn, D. H. (1987). A quantitative protargol stain (QPS) for ciliates: method description and test of its quantitative nature. Mar microb. Fd Webs 2: 83-93

Montagnes, D. J. S., Lynn, D. H. (1989). The annual cycle of Mesodinium rubrum in the waters surrounding the Isles of Shoals, Gulf of Maine. J. Plankton Res. 11 193-201

Montagnes, D. J. S., Lynn, D. H., Roff, J. C., Taylor, W D. (1988a). The annual cycle of hetertrophic planktonic ciliates in the waters surrounding the Isles of Shoals, Gulf of Maine: an assessment of their trophic role. Mar. Biol. 99: $21-30$

Montagnes, D. J. S., Lynn, D. H., Stoecker, D. K., Small, E. B. (1988b). Planktonic ciliates with chloroplasts: taxonomic descriptions of one new species and redescriptions of four species in the family Strombidiidae (Ciliophora. Oligotrichida). J. Protozool. 35: 189-197

Oakley, B. R., Taylor, F. J. R. (1978). Evidence for a new type of endosymbiotic organisation in a population of the ciliate Mesodinium rubrum from British Columbia. Biosystems (Amsterdam) 10: 361-369

Packard, T. T., Blasco, D., Barber, R. T (1978). Mesodinium rubrum in the Baja California upwelling system. In: Boje, R., Tomczak, M. (eds.) Upwelling Ecosystems. SpringerVerlag, Berlin, p. 73-89

Parducz, B. (1966). Ciliary movement and coordination in ciliates. Int. Rev. Cytol. 21: 91-128

Parsons, T R., Blackbourn, D. J. (1968). Pigments of the ciliate Mesodinium rubrum (Lohmann). Neth. J. Sea Res. 4: 27-31

Parsons, T R., Thomas, W H., Siebert, D., Beers, J. R., Gillespie, P., Bawden, C. (1977). The effect of nutrient enrichment on the plankton community in enclosed water columns. Int. Rev. ges. Hydrobiol. 62: 565-572

Platt, T., Gallegos, C. L., Harrison, W G. (1980). Photoinhibition of photosynthesis in natural assemblages of marine phytoplankton. J. mar. Res. 38: 687-701

Powers, P. B. A. (1932). Cyclotrichium meunieri sp nov. (Protozoa. Ciliata); cause of red-water in the Gulf of Maine. Biol. Bull. mar. biol. Lab., Woods Hole 63: 74-80

Purdie, D. A., Garcia, C. A. E. (1988). The use of airborne thematic mapper data in studying the effect of tidal state on the distribution of phytoplankton blooms in Southampton Water. Proc. NERC 1987 airborne campaign workshop. University of Southampton, U.K., p. 195-203

Purdie, D. A., Garcia, C. A. E., Crawford, D. W (1988). The distribution of Mesodinjum blooms in Southampton Water. Remote sensing studies using the airborne thematic mapper. Proc. NERC 1986 airborne campaign workshop, Institute of Hydrology, Wallingford, U.K., p. 143-147

Raymont, J. E. G., Carrie, B. G. A. (1964). The production of zooplankton in Southampton Water. Int. Rev. ges. Hydrobiol. 49: 185-232

Reid, F. M. H., Fuglister, E., Jordan, J. B. (1970). Phytoplankton taxonomy and standing crop. In: Strickland, J. D. H. (ed.) The ecology of the plankton off La Jolla, California, in the period April through September, 1967. Bull. Scripps Instn Oceanogr. (New Ser.) 17: 51-66

Reid, F. M. H., Stewart, E., Eppley, R. W., Goodmann, D. (1978). Spatial distributions of phytoplankton species in chlorophyll maximum layers off southern California. Limnol. Oceanogr. 23: 219-226

Revelante, N., Gilmartin, M. (1983). The microzooplankton distribution in the northern Adriatic Sea with emphasis on the importance of ciliated protozoans. Oceanol. Acta 6: 407-417

Revelante, N., Gilmartin, M. (1987). Seasonal cycle of the 
ciliated protozoan and micrometazoan biomass in a Gulf of Maine estuary. Est. cstl Shelf Sci. 25: 581-598

Robinson, I. S., Holligan, P. M. (1987). Developments in ocean colour research in the U.K. Ocean Colour. Proceedings of an ESA Workshop, Villefranche-sur-Mer, November 1986 , ESA Publications

Royal Commission (1911). Nuisances due to excessive growth of green seaweeds in Belfast Lough. Seventh Report of the Royal Commission on Sewage Disposal, Wyman and Sons, London

Ryther, J. H. (1967). Occurrence of red-water off Peru. Nature, Lond. 214: 1318-1319

Sampayo, M. A. de M., Cabecadas, G. (1981). Occurrence of red-water off Algarve. Bol. Inst. Nac. Invest. Pescas, Lisboa 5: 63-87

Sanders, R. W. (1987). Tintinnids and other microzooplankton - seasonal distributions and relationships to resources and hydrography in a Maine estuary. J. Plankton Res. 9: 65-77

Savage, P. D. V (1965). Preliminary observations on the phytoplankton of Southampton Water. Br. phycol. Bull. 2: 515- 516

Savage, P. D. V. (1967). Some features of the phytoplankton and its production in Southampton Water. Challenger Rep. 19: 41

Sellner, K.G. (1981). Primary productivity and the flux of dissolved organic matter in several marine environments. Mar. Biol. 65: 101-112

Setchell, F. W., Boisseau, D. W., Packard, T T. (1978). Respiration and ETS activity in the ciliate Mesodinium rubrum. In: Packard, T T., Blasco, D., Jones, V. (eds.) Experiments with nitrate reductase and ETS in plankton from the Peru upwelling system. CUEA tech. Rep. No. 54, p. 79-83

Sherr, E. B., Sherr, R. D., Fallon, R. D., Newell, S. Y (1986). Small aloricate ciliates as a major component of the marine heterotrophic nanoplankton. Limnol. Oceanogr. 31: $177-183$

Sieburth, J. McN., Estep, K. W. (1985). Precise and meaningful terminology in marine microbial ecology. Mar microb. Fd Webs 1: $1-16$

Sieburth, J. McN., Smetacek, V., Lenz, F. (1978). Pelagic ecosystem structure: Heterotrophic compartments of the plankton and their relationship to plankton size fractions. Limnol. Oceanogr. 23: 1256-1263

Small, E. B., Lynn, D. H. (1985). Phylum Ciliophora. In: Lee, J. J., Hutner, S. H., Bovee, E. C. (eds.) An illustrated guide to the Protozoa. Society of Protozoologists, Lawrence, Kansas, p. 393-440

Smetacek, V (1981). The annual cycle of protozooplankton in the Kiel Bight. Mar Biol. 63: 1-11

Smith, W O., Barber, R. T (1979). A carbon budget for the autotrophic ciliate Mesodinium rubrum. J. Phycol. 15: $27-33$

Sorokin, Yu. I. (1979). The red-tide in the region of the Peruvian upwelling. Doklady Biol. Sci. 249: 253-256. English translation, Dokl. Akad. Nauk. SSSR, Ser Biol. (1980): 1263-1266

Sorokin, Yu. J. (1981). Microheterotrophic organisms in marine ecosystems. In: Longhurst, A.R. (ed.) Analysis of Marine Ecosystems. Academic Press, London, p. 293-342

Sorokin, Yu. I., Kogelschatz, J. (1979). Analysis of heterotrophic microplankton in an upwelling area. Hydrobiologia 66: 195-208

Soulsby, P. G., Mollowney, M., Marsh, G., Lowthion, D.

This review was presented by Dr D. K. Stoecker, Woods Hole, Massachusetts, USA
(1984). The role of phytoplankton in the dissolved oxygen budget of a stratified estuary. Wat. Sci. Tech. 17. 745-756

Stoecker, D. K., Davis, L. H., Anderson, D. M. (1984). Fine scale spatial correlations between planktonic ciliates and dinoflagellates. J. Plankton Res. 6: 829-842

Stoecker, D. K., Michaels, A. E., Davis, L. H. (1987). Large proportion of marine planktonic ciliates found to contain functional chloroplasts. Nature, Lond. 326: 790-792

Stoecker, D. K., Silver, M. W., Michaels, A. E., Davis, L. H. (1988). Obligate mixotrophy in Laboea strobila, a ciliate which retains chloroplasts. Mar. Biol. 99: 415-423

Stoecker, D. K., Taniguchi, A., Michaels, A. E. (1989). Abundance of autotrophic, mixotrophic, and heterotrophic planktonic ciliates in shelf and slope waters. Mar. Ecol. Prog. Ser. 50: 241-254

Takahashi, M., Hoskins, K. D. (1978). Winter condition of marine plankton populations in Saanich Inlet, B.C. Canada. II. Microzooplankton J. exp. mar. Biol. Ecol. 32: $27-37$

Takahashi, M., Thomas, W. H., Siebert, D. L. R., Beers, J. R. Koeller, P., Parsons, T. R. (1975). The replication of biological events in enclosed water columns. Arch. Hydrobiol. 76: $5-23$

Tamar, H. (1971). Mesodinium fimbriatum Stokes, 1887, a ciliate with bifurcated and barbed cirri. Acta Protozool. 9: 209-222

Tangen, K. (1978). Nets. In: Soumia, A (ed.) Phytoplankton manual. Monographs on oceanographic methodology 6. Unesco Press, Paris, p. 50-58

Taylor, F. J. R. (1982). Symbioses in marine microplankton Annls Inst. océanogr., Paris, Fasc. Suppl 58: 61-90

Taylor, F. J. R., Blackbourn, D. J., Blackbourn, J. (1969) Ultrastructure of the chloroplasts and associated structures within the marine ciliate Mesodinium rubrum (Lohmann). Nature, Lond. 224: 819-821

Taylor, F. J. R., Blackbourn, D. J., Blackbourn, J. (1971). The red-water ciliate Mesodinium rubrum and its 'incomplete symbionts' A review including new ultrastructural observations. J. Fish. Res. Bd Can. 28: 391-407

Throndsen, J. (1978a). Preservation and storage. In: Sournia, A. (ed.) Phytoplankton manual. Monographs on oceanographic methodology 6. Unesco Press, Paris, p. 69-74

Throndsen, J. (1978b). Productivity and abundance of ultraand nanoplankton in Oslofjorden. Sarsia 63: 273-284

Tumantseva, N. I. (1985). Red tide in the Black Sea. Oceanology, Wash. 25: 99-101

Venrick, E. L. (1978). Water bottles. In: Sournia, A. (ed.) Phytoplankton manual. Monographs on oceanographic methodology 6. Unesco Press, Paris, p. 33--40

Venrick, E. L., Beers, J. R., Heinbokel, J. R. (1977). Possible consequences of containing microplankton for physiological rate measurements. J. exp. mar Biol. Ecol. 26: 55-76

White, A. W., Sheath, R. G., Hellebust, J. A. (1977). A red tide caused by the marine ciliate Mesodinium rubrum in Passamaquoddy Bay, including pigment and ultrastructure studies of the endosymbiont. J. Fish. Res. Bd Can. 34: $413-416$

Williams, P. J. LeB. (1980). Phytoplankton in Southampton Water. In: The Solent Estuarine System. NERC Publications, Series C, No. 22: 73-75

Zaika, V. Ye. Averina, T Yu. (1968). Proportions of infusoria in the plankton of Sevastopol Bay, Black Sea. Oceanology, Wash. 8: 843-845

Manuscript first received: December 29, 1988

Revised version accepted: August 2, 1989 